\title{
NOTAS SOBRE EL PAN PINTADO
}

Consolación González Casarrubios

El pan, según el Diccionario de la Real Academia, es una porción de masa de harina y agua que después de fermentada y cocida en horno sirve de principal alimento al hombre, entendiéndose que es de trigo cuando no se expresa otro grano. Aquí no vamos a referirnos al pan de uso común, sino a panes especiales por su forma, decoración, uso o simbolismo que podríamos agrupar con la denominación de "pan pintado".

El origen del pan pintado tuvo lugar por la necesidad de hacer una señal diferente en cada uno de los panes para distinguirlos cuando éstos se cocían en hornos comunales. Para ello se utilizó una "pintadera" hecha de diferentes materias y que normalmente llevaba las iniciales del ama de casa que había fabricado el pan o de los padres de ésta, ya que era costumbre que la hija mayor heredase la pintadera o sello para marcar el pan. En algunos lugares en que no existía la pintadera, se marcaba el pan con un cuchillo, haciendo unas rayas, una cruz, etc., pero este procedimiento era menos seguro que el empleo de la pintadera, pues al cocerse el pan se perdía en parte este dibujo o podía variar algo, dando motivo a confusiones e incluso riñas en algunos casos.

Posteriormente la pintadera no se utilizó únicamente con esta misión primordial de evitar la confusión de unos panes con otros, sino con un fin decorativo, y así la define la Real Academia: "Instrumento que se emplea para adornar con ciertas labores la cara superior del pan u otras cosas.» La decoración de los panes no se hacía todos los días, sino solamente en ocasiones especiales, como bodas, fiestas, etc. Esta función de la pintadera como adorno o representación simbólica para solemnizar ciertas ocasiones es la única que se conserva hoy en España al no hacerse ya los panes en cada casa ni llevarlos a cocer a hornos comunales. 
A modo de ejemplo podemos citar varios lugares, entre otros muchos, donde se hacen panes pintados.

En Santo Domingo de la Calzada, pueblo riojano muy ligado a la vida y milagros de su fundador, Santo Domingo, antes de comenzar las fiestas, que tienen lugar a mediados de mayo, el día 1 de este mes se reparte el "pan del Santo" entre los cofrades para conmemorar el pan que repartía Santo Domingo entre los peregrinos y necesitados cuando pasaban por allí camino de Compostela.

Este "pan del Santo» o "mollete» es pequeño, de forma redondeada y muy delgado. De color amarillento, conseguido con yema de huevo o azafrán, según informa el panadero que los realiza, Justi Mendi. Lo más curioso de este pan es la decoración que lleva en el centro, en la que aparece la imagen de Santo Domingo representado como un anciano con un cayado y alrededor los símbolos de algunos de sus más conocidos milagros, entre los múltiples que el Santo hizo, que son setenta y nueve, según dice el doctor González de Texada, autor de El Abraham de la Rioja.

La pintadera empleada en Santo Domingo es llamada "marco del Santo" y es de madera. En ella encontramos representados al gallo y a la gallina, que conmemoran el milagro por el que fueron resucitados estos animales después de asados, como oímos en el dicho popular: "Santo Domingo de la Calzada, que cantó la gallina después de asada», recordándonos lo sucedido:

"Durante el siglo xv pasan los romeros a Compostela por el Camino Real Francés. Un matrimonio alemán va en peregrinación con un hijo. Se hospedan en la posada de la ciudad, donde les sirve la hija del dueño, ligera y casquivana. Hace temblar a la muchacha el mancebo alemán, pero al no hacerla caso, ésta le mete en su zurrón una copa de plata. Apenas se van, la muchacha denuncia el robo. Le encuentran y como castigo tiene la horca; los padres, doloridos, siguen su peregrinación. $\mathrm{Al}$ regreso de Compostela, la madre quiere ver el cuerpo del hijo muerto que sigue colgando de la horca. Al acercarse, la madre oye la voz de éste que le habla: "¡Madre mía!" Le dice: "No lloréis, pues Santo Domingo me ha protegido, ya que me encomendé a él en mis últimos momentos; ir a la justicia y contadlo."

„En la Calzada, en el Barrio Viejo, vive el Corregidor; van a la casa y le cuentan lo sucedido; éste, que se disponía a comer, dice: "Sí, sí, vuestro hijo tiene tanta vida como este gallo y esta gallina, que sirven asados a mi mesa." Al momento de ir a cortarlos ve cómo se le- 
vantan las aves asadas, se cubren de plumas y empiezan su cacareo. El Cabildo, desde entonces, alimenta a los dos animales, que tienen su puesto de honor en la Catedral» (1).

Estas dos aves están colocadas dentro de una gran jaula, frente al sepulcro del Santo, para conmemorar este milagro.

En la patre superior izquierda del pan se ve la horca del peregrino. $\mathrm{Y}$ el símbolo de este milagro no sólo aparece en este pan, sino que también lo vemos en la procesión de Las Doncellas del día 11, en la que un niño lleva un palo y sobre éste la horca con el peregrino, que es una figura hecha con masa de pan del mismo color amarillento que los otros panes.

Otros milagros podemos ver representados en el pan de Santo Domingo, como es el árbol con la hoz, símbolo del milagro que hizo el Santo al talar un bosque con una hoz gastada. Esta hoz se guarda en una hornacina en la Catedral. Encontramos otros símbolos, como son la carreta tirada por bueyes, y la rueda, que también aparece en la procesión cívico-religiosa de La Rueda el día 11 de mayo por la tarde. Se lleva en andas y va adornada con ramas de arbusto, obleas de colores y panes semejantes al citado (fotos 1 y 3 ). Esta rueda se cuelga en la Catedral al lado del sepulcro del Santo y permanece allí durante quince días.

Este pan la primera vez que lo vemos aparecer en las fiestas dedicadas a Santo Domingo es con motivo de la procesión de Las Prioras, que en este desfile procesional «visten de negro y se tocan con el clásico cestaño blanco, del que pende un tul que cubre el busto de la feliz portadora. Sobre el cestaño, un popular mollete. Lo blanco simboliza pureza de esposas y madres; lo negro, expresión de penas y dolores del mundo. Estas damas que desfilan son las esposas o madres de los componentes de la Cofradía, más una representante de la panadería donde se elaboran las hogazas del almuerzo. La gaita y danzadores acompañan con música de siglos. Terminado este desfile se dirigirá la Cofradía a la panadería para contar y pesar las hogazas. Acto sencillo, pero tradicional. Hecho esto, son transportadas las cincuenta hogazas de dos kilos cada una a la casa del Santo en caballerías» (2).

Al hablar de las fiestas calceatenses no podemos pasar sin referirnos más detalladamente a la procesión de Las Doncellas. En este des-

(1) Leyendas y tradiciones de La Rioja, por Luisa Iravedra y Esperanza Rubio. Instituto de Estudios Riojanos, 1949, pág. 40.

(2) Estampas calceatenses, por J. José Saezniera Uyarra. Edit. Ochoa. Logroño, 1972, pág. 20. 
file toman parte muchachas jóvenes que se ofrecen voluntarias para ser "doncellas del Santo" en ese año. Van vestidas de blanco, a diferencia de las Prioras, que desfilaron el día 10 vestidas de negro. En la cabeza portan los típicos "cestaños», como las Prioras lo hicieron el día anterior. Estos cestaños son unos cestos de mimbre forrados con tela blanca y tul que les cubre el rostro, van adornados con flores y encima el pan del Santo. Estos cestaños los suelen adornar las monjas o unas mujeres especializadas en esta labor a las que se les da una propina por el trabajo. La Priora se diferencia de las demás doncellas en que ésta, en lugar de llevar en el cestaño solamente el pan del Santo, lleva, además, una imagen pequeña de Santo Domingo. Va al final de las dos filas de doncellas; el número de éstas puede variar: este año de 1975 han desfilado alrededor de 40 doncellas; el número no puede bajar de 13, según lo establecen los cánones. En esta misma procesión hay que destacar a los danzantes; al carro con los bueyes, los cuales encima del yugo llevan unos panes con el mismo sello, pintadera o marca del Santo, pero de distinta forma: son a modo de hoja acorazonada (foto 2); en este carro cubierto con ramas, para quemarlas al hacer el almuerzo del Santo, van unos niños simbolizando a los peregrinos. También desfilan dos mulas con las viandas suficientes para preparar el almuerzo del Santo, entre las que figuran los carneros, que han pastado libremente por las tierras del pueblo debido a un privilegio especial concedido por Alfonso I el Batallador; unas hogazas con la misma imagen grabada, semejantes a los que se reparten cortados en trozos cuando tiene lugar el reparto de la cebolleta. Este reparto es de lo más original, ya que tiene lugar en la casa del Santo; cuando termina la procesión de La Rueda se reparte pan con cebolleta y vino. Reparto de gran emoción para los forasteros y calceatenses, pues se piensa en Santo Domingo, que, remontándonos a la Edad Media, estaría repartiendo alimento a los peregrinos.

Al hablar de estas fiestas dedicadas al Santo fundador hemos visto cómo este pan, que tanto debió repartir Santo Domingo, no ha perdido importancia, aunque hoy día no se reparte a los necesitados, sino a los vecinos del pueblo y a los forasteros que han acudido a Santo Domingo de la Calzada no en peregrinación, sino únicamente para contemplar esta increíble fiesta que tan ligada a Santo Domingo permanece.

Distante de Santo Domingo de la Calzada encontramos otro pueblo donde también se decoran unos panes con la pintadera; esto sucede con motivo de las fiestas de San Jorge, el 23 de abril, en Villanueva de 
Alcardete, provincia de Toledo, casi en el límite con la de Cuenca. Días antes de la fiesta se ofrece un "refresco" por el Ayuntamiento para sacar dinero por medio de donativos que hacen bien en dinero o en especie, es decir, con harina para elaborar estos panes que llaman "cariaes" o "caridades". Se llama caridad porque se reparte el día de la fiesta entre los asistentes al «refresco». Pero la función de las «cariaes» más bien es la de llevarlas a la iglesia para bendecirlas. Este pan bendito luego se puja con el fin de sacar fondos para el Santo. Una vez benditas, la gente las guarda con aprecio y numerosas son las casas en que aparece este pan bendito colgado de la cabecera de la cama para que San Jorge los proteja.

Este pan, como el de Santo Domingo de la Calzada, se guarda hasta las fiestas del año siguiente, en que es sustituido por otro nuevo. Se recurre a él en caso de enfermedad y son protegidos por el Santo.

Curiosa es la forma de las caridades: encontramos desde una flor hasta un corazón. Además de la forma, otra particularidad es que van decoradas: en el centro llevan grabada la imagen del Santo, San Jorge; esta marca se consigue con un sello de madera o pintadera en que se encuentra grabado. Pero hay que destacar que en este pueblo no llaman pintadera a este sello; más bien lo que forman las pintaderas o «pintaeras» es un conjunto de los más diversos objetos de metal, como pueden ser las manecillas de un reloj, los botones de soldados, las canillas de la máquina, dedales, etc., que se incrustan cuando la masa está tierna. Esta masa no lleva sal ni levadura, es pan ázimo, y para que no suba nada al cocerlo en el horno, a una temperatura especial, se pincha con un alfiler. Se tiene muy poco tiempo dentro del horno y se saca sin tostar, casi blanco. Esto es importante, pues las caridades han de estar blancas. Las mujeres del pueblo, muy entendidas, en seguida le dicen al panadero que no ha estado atento al sacarlas del horno y no han quedado todo lo bien que debían cuando quedan un poco tostadas. Pero aún llevan más decoración estos panes: les ponen unas cintas de colores y flores de papel, a veces, que se van pasando por unos orificios que llevan (foto 4). Tienen tanta importancia las caridades en la fiesta que ¡hasta San Jorge lleva colgada una del cuello!

El molde con la imagen de San Jorge y las "pintaeras» se van pasando de madres a hijas y se los prestan unas vecinas a otras, ya que todas no los tienen. Vemos varios sellos con imágenes diferentes de San Jorge, todas distintas del actual. Me dicen en el pueblo unas mujeres mayores que con motivo de la guerra del 36 quemaron la imagen 
que había. Se podría pensar que fuera algún molde de éstos sacado de esa imagen, pero las estampas que he podido ver no son iguales y aún está por descubrir de qué grabado o imagen han copiado estos sellos o moldes.

«Una costumbre que aún pervive es la de repartir la caridad, que es pan pintado, después de bendecido por el sacerdote, a todo el pueblo y a los forasteros; este agasajo lo hace el Ayuntamiento del lugar, y además del mollete dan un trozo de queso y una taza de vino servido de la jarra maja; es como una comunión colectiva. A esta fiesta convival se llama de la caridad, y al menos en los pueblos de la provincia de Guadalajara es —en muchos una vez al año- en la víspera de las fiestas patronales, como la de San Sebastián, en Montarrón; de San Agustín, en Valdeancheta, etc.» (3). Costumbre muy semejante a las que hemos visto en Santo Domingo de la Calzada y en Villanueva de Alcardete: repartir el pan del Santo o la caridad entre los asistentes a la fiesta, sean vecinos del pueblo o forasteros.

En otros puntos de la geografía española se hacen unos panes con motivo de la fiesta de San Antón; son también unos panecillos pintados que van marcados con el sello, que tiene la "T» simbólica (tau o cruz pintada) del Santo anacoreta y el cerdo que le acompañó en su vida.

En este breve recorrido vemos en todos ellos el sentido simbólico que tiene el pan y el carácter curativo que ya desde las civilizaciones antiguas se le ha dado.

Ya los pueblos mejicanos, antes de la conquista por los españoles, tenían la costumbre de «hacer pequeñas imágenes parecidas a hombres que representaban las montañas coronadas de nubes. A estas imágenes, moldeadas con una pasta hecha de diversos granos, las vestían y ornamentaban con papeles. Algunas personas construían cinco de estas imágenes, otras diez y algunas hasta quince. Después de terminadas las colocaban en el oratorio de cada casa y las daban culto. Cuatro veces en el curso de la noche las traían ofrendas de comida en minúsculas vasijas y la gente cantaba y tocaba la flauta ante ellas todas las horas de oscuridad. Al romper el alba los sacerdotes rompían las imágenes con una herramienta de tejedor, las cortaban la cabeza, arrancaban el corazón y se los presentaban al padre de familia, especialmente los sirvientes, para que comiendo de ellas pudieran librarse de ciertos males

(3) Historias y tradiciones de Guadalajara y su provincia, por Antonio Castillo de Lucas. Guadalajara, 1970, pág. 128. 
a que las personas negligentes en el servicio de los dioses estaban expuestas" (4).

Creían que se comían el espíritu del cereal al comer este pan y así quedaban liberados de los males, que les podían atacar no sólo al cuerpo, sino al alma.

(4) La rama dorada, por J. George Frazer. Méjico, 1944, pág. 587. 

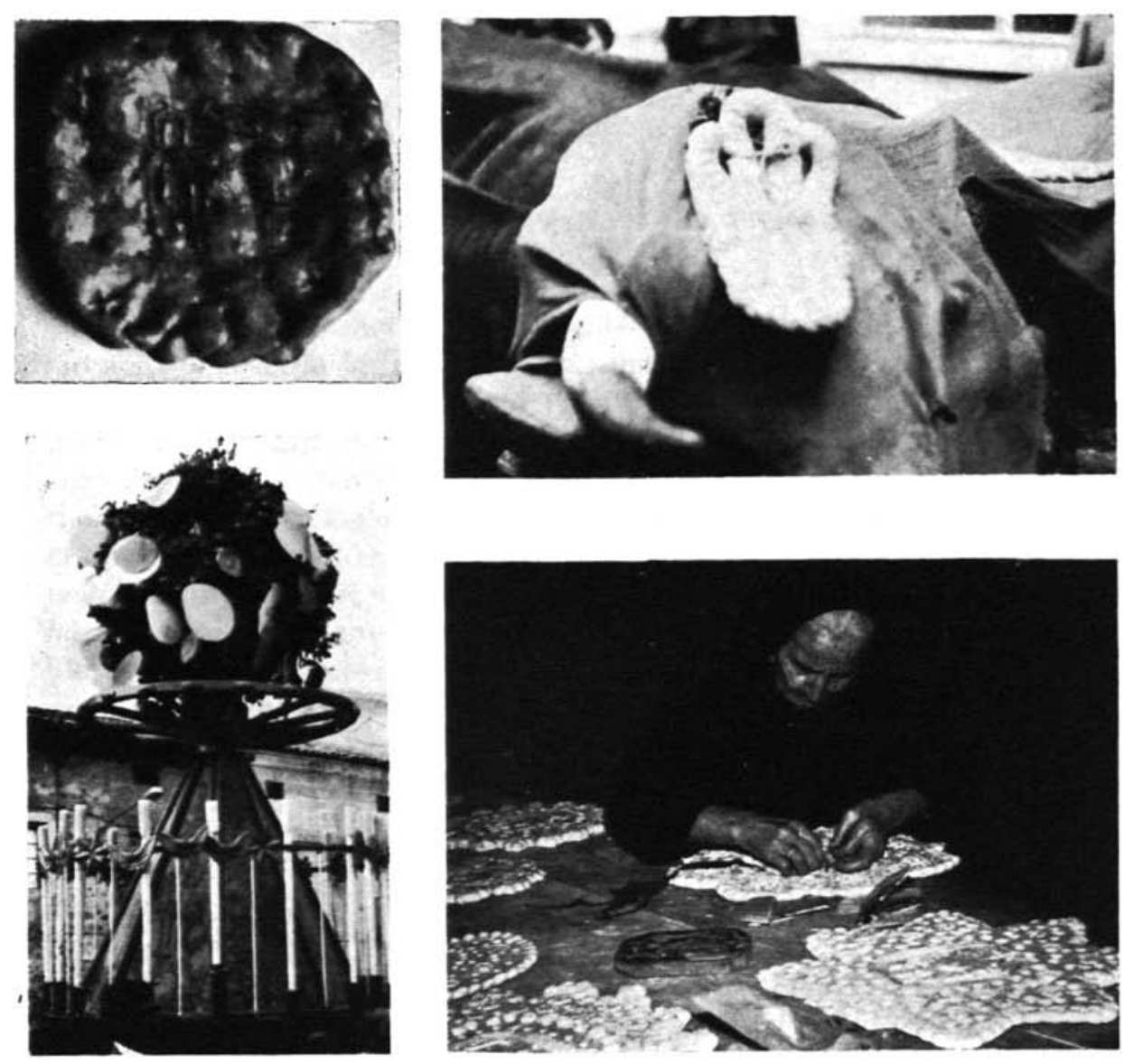

FIG. 1.- «Pan del Santo». Santo Domingo de la Calzada (Logroño).

FIG. 2.- «Pan sobre el yugo de bueyes». Santo Domingo de la Calzada (Logroño).

FIG. 3.- «Rueda de carro llevada en andas en la procesión civíco-religiosa del día 11 de mayo". Santo Domingo de la Calzada (Logroño).

Fig. 4.-Mujer adornando las «caridades» o panes. Villanueva de Alcardete (Toledo). 